\title{
Hulp voor ouderen met psychische klachten
}

\section{Doelgroep}

Dit pittige en pragmatische boek is voor huisartsen, psychologen, psychiaters en poh-ggz. Voor de gemiddelde praktijkondersteuner somatiek is het hogere wiskunde, maar het is een welkom naslagwerk voor degenen met een psychiatrische opleiding en voor degenen die veel te maken hebben met patiënten met een psychische aandoening of daar veel affectie mee hebben.

\section{Inhoud}

Veel ouderen hebben zowel somatische klachten als psychische stoornissen. De rode draad in de ouderenpsychiatrie wordt gevormd door vier begrippen: iedereen heeft een verhaal, behandeling moet een functioneel voordeel hebben, zorgprofessionals zorgen voor zowel de patiënt als de mantelzorger en eenvoud werkt het best.

Net zoals hypertensie, hypercholesterolemie, diabetes en obesitas vaak tegelijkertijd voorkomen bij patiënten met een metabool syndroom, komen bepaalde psychische stoornissen vaak voor met andere psychische stoornissen. Hoe meer psychische stoornissen een patiënt heeft, hoe waarschijnlijker het is dat het om een cluster van psychische aandoeningen gaat. Een voorbeeld daarvan is de casus van Vera, waarin niet haar aanpassingsstoornis maar haar depressieve stoornis en PTSS de symptomen het best verklaarden. De auteurs behandelen dit item uitvoerig. Zij leggen het begrip 'stoornis' uit en lichten toe waarom ze voor deze term hebben gekozen. Met de zes diagnostische D's (Delirium,
Drugs, Diseases, Dementie, Depressieve stoornis, Disrupted sleep), diverse richtlijnen, criteria en tabellen, aanvullende instrumenten en eerste behandelingen vergroot dit boek zowel professionaliteit als interesse om hulp te verlenen aan ouderen met psychische klachten. Als je het boek wilt lezen, laat je dan niet afschrikken door de veelheid aan psychiatrisch jargon. Het wordt vaak verduidelijkt of is op te zoeken.

\section{Oordeel}

De auteurs pretenderen niet dat dit boek de DSM-5 kan vervangen. Het is een diagnostisch instrument waarmee je de DSM- 5 in de praktijk kunt gebruiken. Het besef dat in Nederland 14 procent van de 65- tot 75-jarigen en 19 procent van de 75-plussers psychische stoornissen heeft (in 2040 is het aantal 65-plussers gegroeid tot 4,6 miljoen!), en het besef dat de meeste ouderen met psychische klachten zich melden in de eerstelijnsgezondheidszorg, nodigt al uit om de aanschaf serieus in overweging te nemen. Door het warme pleidooi voor een therapeutische alliantie met de patiënt én mantelzorger, de richtlijnen slaaphygiëne, de classificatiecriteria slaapapnoe en het korte maar mooie stukje over bespreekbaar maken van seksualiteit, verdient dit stevige boek een goede waardering. Ook het onderzoek naar de status mentalis, de verkorte DSM-5-criteria voor veelvoorkomende diagnoses bij ouderen, de vele tips, figuren en tabellen bieden meerwaarde.

Martien Vrolijk

\section{BOEK}

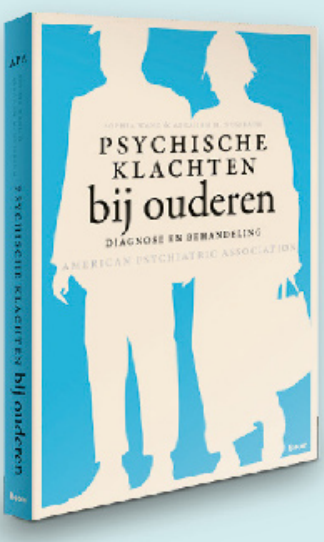

„Wang $S$, Nussbaum AM.

Psychische klachten bij ouderen.

Diagnose en behandeling $* * * / * * * *$

- Amsterdam: American Psychiatric Association / Boom uitgevers, 2018

- Aantal bladzijden: 366

- Prijs € 42,95

- ISBN 9789024409112

\section{Waardering}

* zeer matig boek

** matig boek

*** aardig boek

$* * * *$ goed boek

$* * * * *$ topper! 